\title{
Vatandaşlık Teorileri Bağlamında Dinin Kamusal Taleplerine İlişkin Karşılaştırmalı Bir İnceleme*
}

\section{The Public Demands of Religion: A Comparative Study of Citizenship Theories**}

\author{
Özlem ÜLKER SHAHAVATOV \\ Arş. Gör. Dr., Yalova Üniversitesi, İslami Ilimler Fakültesi, Din Sosyolojisi Anabilim Dalı \\ Research Assistant Dr., Yalova University, Faculty of Islamic Studies, Department of Sociology of Religion \\ Yalova, Turkey \\ ozlem.shahavatov@yalova.edu.tr \\ orcid.org/0000-0001-7724-8010
}

\author{
Makale Bilgisi / Article Information \\ Makale Türü / Article Types \\ Geliş Tarihi / Received \\ : Araştırma Makalesi / Research Article \\ Kabul Tarihi / Accepted \\ :09 Mart / March 2019 \\ Yayın Tarihi / Published \\ :05 Nisan / April 2020 \\ Yayın Sezonu / Pub Date Season : Haziran / June \\ Cilt / Volume: 7 - Sayı / Issue: 1 - Sayfa / Pages: 125-149
}

Atıf / Cite as

Ülker Shahavatov, Özlem. "Vatandaşlık Teorileri Bağlamında Dinin Kamusal Taleplerine Iliş̧kin Karşılaştırmalı Bir Inceleme". Bülent Ecevit Üniversitesi Illahiyat Fakültesi Dergisi, 7/1 (2020), 125-149.

Doi: $10.33460 /$ beuifd.700634

İntihal / Plagiarism

Bu makale, en az iki hakem tarafından incelendi ve intihal içermediği teyit edildi.

This article has been reviewed by at least two referees and scanned via a plagiarism software.

Yayın Hakkı / Copyright ${ }^{\circ}$

Zonguldak Bülent Ecevit Üniversitesi, İlahiyat Fakültesi tarafından yayınlanmıștır. Tüm hakları saklıdır.

Published by Zonguldak Bulent Ecevit University, Faculty of Theology, Zonguldak, Turkey. All rights reserved.

Öz: Küreselleşme süreçleri, çokkültürlü toplumların ortaya çıkışına ve bununla birlikte homojen bir topluma dayalı modern vatandaşlık anlayışının dönüşümüne ilişkin taleplerin yükselişine yol açmıştır. Eş zamanlı olarak, modernite ile benimsenen din-devlet ayrılığının sekülerist yorumları nedeniyle özel alana özgü bir olgu konumuna indirgenen dinin de kamusal taleplerinin yükselişi söz konusu olmuştur. Bu makale, küreselleşme ile birlikte ortaya çıkan, vatandaşılı ve dine dair bu eş zamanlı gelişmelerin birbiriyle ilişkisini ortaya koymayı hedeflemekte ve liberal teori, komüniteryan teori, katılımcı cumhuriyetçilik ve ılımlı post-modern çoğulculuktan oluşan dört temel vatandaşlık teorisinin seçtiğimiz temsilcilerinin, modern vatandaşlığın krizi karşısında, günümüz çokkültürlü/çok dinli toplumsal yapıyı dikkate alarak ürettikleri vatandaşlık

\footnotetext{
* Bu çalışma Eylül 2019 tarihinde tamamlanan Küreselleşme Sürecinde Vatandaşlık ve Din başlıklı doktora tezi esas alınarak hazırlanmıştır.

** This article is extracted from my doctorate dissertation entitled Citizenship and Religion in the Globalization Process (Marmara University, Institute of Social Sciences, İstanbul / Turkey, September 2019).
} 
anlayışlarından hareketle dinin kamusal taleplerine ilişkin sundukları cevapları karşılaştırmalı olarak ele almaktadır. Bu doğrultuda, vatandaşlık ve dine dair sorunsallar, bireysel haklar-grup/topluluk hakları, kamusal alan-özel alan, anayasal ilkeler ve demokrasi, kimlik-aidiyet ve çok-hukukluluk başlıkları altında tartışılmakta, devletin tarafsızlığı ve din özgürlüğü arasındaki dengenin sağlanmasında ortaya çıkabilecek açmazlar irdelenmektedir. Teorilerin yaklaşımlarındaki farklılaşmaların felsefi, siyasi temelleri ile birlikte sosyolojik temelleri vurgulanmaktadır.

Anahtar Kelimeler: Vatandaşlık, Din, Küreselleşme, Liberalizm, Komüniteryanizm, Katılıma Cumhuriyetçilik, Ilımlı Post-modern Çoğulculuk.

Abstract: Globalization processes have led to the emergence of the multicultural societies and accordingly the rise of the demands for the transformation of modern citizenship understanding based on a homogeneous society. Simultaneously, the public demands of religion which was reduced to a private sphere because of the secularist interpretations of the religion-state separation adopted with modernity, also increased. This article aims to reveal the relationship between these simultaneous developments in citizenship and religion and discusses the responses of the citizenship theories, which consist of liberal theory, communitarian theory, participatory republicanism and moderate post-modern pluralism to the public demands of religion considering contemporary multicultural/multi religious social structure. In this regard, the issues of citizenship and religion are discussed under the headings of individual rights / group rights, public sphere-private sphere, constitutional principles and democracy, identitybelonging and legal pluralism, and it is examined the dilemmas that may arise in ensuring the balance between the impartiality of the state and freedom of religion. The philosophical, political and sociological bases of the differences in the approaches of the theories are emphasized.

Keywords: Citizenship, Religion, Globalization, Liberalism, Communitarianism, Participatory Republicanism, Moderate Post-modern Pluralism.

\section{Giriş}

20. yüzyılın sonlarına doğru, küreselleşme ve postmodernizasyon gibi makro süreçlerin etkisi ile ortaya çıkan siyasal-toplumsal gelişmeler, modern demokrasilerin devlet-birey ilişkilerini düzenlemek üzere geliştirmiş oldukları modern ulus-devlet vatandaşlığını sosyal bilimlerin tartışmalı konularından biri haline getirmiştir. Vatandaşlık konusu siyasi, hukuki, felsefi bir konu olmakla birlikte, meselenin sosyolojik boyutunun da oldukça önemli olduğu ortaya çıkmıştır. Modern vatandaşlık, 1960'lardan beri barış, çevre, cinsiyet gibi konulara odaklanan sosyal hareketlerin, Avrupa'daki kimlik politikalarına karşı çıkışları ile sorgulanmaya başlamış, 'Savaş sonrası Avrupa'da endüstrileşmiş ülkelerin acil iş

1 Charles Tilly, "Citizenship, Identity and Social History", Citizenship, Identity and Social History, ed. Charles Tilly (New York: Cambridge University Press, 1996), 1. 
gücü ihtiyaçlarının karşılanması için uluslararası yoğun bir işçi göçünün yaşanması sonucu Batılı toplumların etnik ve ulusal kompozisyonlarının çeşitlenmesi, karmaşıklaşması ${ }^{2}$ ile birlikte ulus-devlet ve nasyonaliteye dayalı homojen toplum denklemi sarsılmıştır. 1990'larla birlikte ise, Soğuk Savaş'ın bitişi, kimlik temelli taleplerin artışı ile ciddi bir meydan okuma ve revizyon talebi ile karşı karşıya kalmıştır. Bu doğrultuda özellikle 1980'lerin sonu ve 1990'lar itibariyle modern vatandaşlığın krizi ve revizyonuna yönelik ciddi bir literatür ortaya çıkmıştır. Liberal teori ve cumhuriyetçi teorinin yenilenen versiyonları, komüniteryan teori, radikal demokrasi, çokkültürcülük gibi teoriler ile feminist yaklaşımlar, ekolojik vatandaşlık, ulus-sonrası vatandaşlık, kozmopolitan vatandaşlık, küresel vatandaşlık, Avrupa vatandaşlığı gibi vatandaşlık anlayışları bu literatürün örneklerini teşkil etmektedir.

Vatandaşlıkla yaklaşık olarak eş zamanlı dönemlerde bir diğer meydan okuma ise dini özel bir olgu konumuna indirgeyen sekülerist bakış açılarına getirilmiştir. Farklı sekülerleşme tecrübeleri, dinin çeşitli siyasal/toplumsal hareketlerde motive edici bir unsur olarak ortaya çıkması ve Batı'ya yoğun kitlesel göçler ile birlikte dinin kamusal görünürlüğü ve taleplerindeki artış; toplumsal çalışmalarda dinin toplumdaki rolünün yok sayılamayacağını göstermiş; sekülerleşme teorilerinin ortaya attığı bazı iddiaların yanlış olduğunu ileri süren bir literatür ortaya çıkarmıştır. "Desekülerizasyon", "yeniden sakralizasyon", "kamusal din", "post-sekülerizm" gibi yaklaşımlar bu literatürün örnekleri olarak karşımıza çıkmaktadır.

$\mathrm{Bu}$ iki toplumsal/siyasal gelişme ve literatürden hareketle, bu makalede aşağıda isimlerini zikredeceğimiz dört temel vatandaşlık teorisinin vatandaşıık yaklaşımları ile dinin kamusal taleplerine ürettikleri cevapları, çözümleri ve açmazlarını karşılaştırmalı olarak bireysel haklar-kolektif haklar, kamusal alanözel alan, anayasal ilkeler ve demokrasi, kimlik-aidiyet ve çok-hukukluluk başlıkları altında inceleyeceğiz. Bu doğrultuda geniş bir literatür içerisinden bir sınırlandırma yapmanın gereğine binaen, liberal teoriyi John Rawls'un "siyasal liberalizm" anlayışı, komüniteryan teoriyi Charles Taylor'ın "tanınma politikası", katılımcı cumhuriyetçiliği Jürgen Habermas'ın "post-seküler toplum" ve "müzakereci demokrasi" anlayışları, son olarak ılımlı post modern çoğulculuğu (radikal demokrasi ve çokkültürcülük) ise Chantal Mouffe'un "radikal demokratik vatandaşlık", Will Kymlicka'nın "çokkültürlü vatandaşlık" ve Iris M. Young'ın "farklılaştırılmış vatandaşlık" anlayışları üzerinden inceleyeceğiz.

2 Yasemin Nuhoğlu Soysal, Limits of Citizenship: Migrants and Postnational Membership in Europe (Chicago: The University of Chicago Press, 1994), 1-2; Yasemin Nuhoğlu Soysal, "Changing Citizenship in Europe: Remarks on Postnational Membership and the National State", Citizenship, Nationality and Migration in Europe, ed. David Cesarani-Mary Fulbrook (London: Taylor\&Francis e-Library, 2003), 18. 


\section{Birey Hakları-Topluluk Hakları}

Günümüzde çokkültürlü Batılı demokratik toplumların dinle ilgili olarak karşılaştıkları temel meselelerden birisi dindar vatandaşların kamusal alanda görünürlük, din-ibadet özgürlüğü taleplerinin karşılanmasında; bireysel temel hak ve özgürlüklerin, herkes için aynı olarak belirlenmiş vatandaşlık haklarının yeterliliği meselesidir. Temel felsefesi, insanları, din, dil, ırk, etnisite, sınıf vb. farklılıkların toplumsal yaşamlarında imtiyaz veya dezavantaj sağlamaksızın, eşit ve özgür kılmak olan modern vatandaşlığın herkes için sağladığı aynı hak ve özgürlükler, ulus-devlet ve homojen ulus yapısının giderek aşındığı küreselleşen dünyada farklı dinlere, dini inançlara sahip insanların din özgürlüklerini kısıtlamadan kamusal alanda varoluşlarını temin edebilecek midir? Bugün yaşanan tartışmada bireysel hakların yeterli olduğunu, eşitlik ve özgürlük ilkelerini sağlayan bir gereklilik olduğunu, topluluk hakları, topluluğa özgü haklar, kolektif haklar gibi taleplerin ise bu ilkeleri ortadan kaldıracağını savunanlar olduğu gibi; çokkültürlü toplumlardaki farklılıkları görmezden gelerek herkesi eşitlemenin aslında eşitsizlik üretebileceği ve özgürlükleri kısıtlayıcı olabileceği, farklı grupların farklı taleplerinin karşılanması için farklılaştırılmış vatandaşlık anlayışı ve gruba özgü haklar anlayışlarının benimsenmesi gerektiği fikrini savunanlar da vardır. Söz konusu durum, vatandaşlık çalışmaları literatüründeki evrenselcilikpartikülarizm, bireysel haklar-grup/topluluk hakları gibi dikotomiler ekseninde tartışılmaktadır. Bu bağlamda, vatandaşlık teorilerinin, dinle ilişkili çokkültürlü, demokratik, seküler düzende yükselen taleplere, meselelere bu dikotomiler ekseninde verdikleri cevapların bir tartışmasını ele alacağız.

Öncelikle bu tartışmada, liberal ve cumhuriyetçi teorilerin genel çizgileri itibariyle, evrenselci bir bakış açısını benimserken, komüniteryan ve çokkültürcü teorilerin partikülarist bir bakış açısını benimsediklerini ifade etmek gerekir.

Liberal teori, birey-devlet-toplum-topluluk ilişkilerinde bireyi önceler. Bireyin hak ve özgürlükleri ne devlet ne de toplum tarafından kısıtlanabilir veya ortadan kaldırılabilir, ${ }^{3}$ onlar dokunulmazdır. Bu doğrultuda, vatandaş bireysel hak ve özgürlüklere sahip olarak politik toplumun bir üyesidir. Başkalarının hak ve özgürlüklerine saygı göstermek dışında herhangi bir yükümlülüğü yoktur. Yasa, haklar konusunda evrensel olmalı, herkes için aynı olmalıdır. Ancak bu şekilde olursa herkese eşit özgürlük sağlanabilir. Bu şekilde, liberal teori, evrenselci bir yaklaşımla, hem herkesin politik topluluğa üyeliğini hem de üyeler arasındaki eşitliği ve adaleti sağlamayı hedeflemektedir. ${ }^{4}$

3 Adrian Oldfield, "Vatandaşlık Doğal Olmayan bir Pratik mi?", çev. Can Cemgil, Vatandaşlığın Dönüşümü: Üyelikten Haklara, haz. Ayşe Kadıoğlu (İstanbul: Metis Yayınları, 2. Basım, 2012), 95-96.

4 Michael Lister-Emily Pia, Citizenship in Contemporary Europe (Edinburgh: Edinburgh University Press, 2008), 1011. 
Liberal teorinin temsilcisi olan John Rawls, evrenselci-partikülarist ayrışmasında bireysel haklardan yana, evrenselci bir bakış açısına sahiptir. Rawls, "siyasal liberalizm" düşüncesi doğrultusunda, benimsedikleri kapsamlı doktrinler nedeniyle birbirlerinden oldukça farklılaşmış vatandaşlardan oluşan bir toplumda siyasal adaletin iki ilkesi olduğunu iddia eder ve birinci ilkeyi şu şekilde tanımlar: "Herkesin tamamıyla yeterli eşit temel haklar ve özgürlükler düzenine sahip olmak konusunda eşit hakkı bulunmaktadır ve bu düzen herkes için aynıdır, bu düzende, eşit siyasal özgürlüklerin, ama sadece bu özgürlüklerin, değerleri eşit olarak sağlanır." ${ }^{5}$ Ekonomik ve toplumsal eşitsizlikleri tamamen ortadan kaldırmanın imkansızlığı karşısında Rawls, siyasal adaletin; birinci ilke gereğince, vatandaşlara eşit temel hak ve özgürlükler verilmesi, ikinci ilke gereğince ise, adil bir fırsat eşitliği sağlanması ve mevcut eşitsizliklerin en dezavantajlı konumdaki vatandaşın en çok lehine olacak şekilde olması ile sağlanabileceğini vurgulamaktadır. ${ }^{6}$ Vatandaşlar, "bilgisizlik peçesi" ardında, "başlangıç durumu"nda, kendi özel konumlarını, doktrinlerini bilmeksizin toplumun en dezavantajlı bireyinin en çok çıkarına olacak şekilde ilkeleri belirlemeye çalıştıklarında siyasal adalet tesis edilebilecektir. ${ }^{7}$ Öte yandan, Rawls hakkın iyiye önceliği prensibini benimser. Herhangi bir iyi anlayışının, bireyin hak ve özgürlüklerini kısıtlamasına ya da onun önüne geçmesine izin vermez. Ona göre, bireyler herhangi bir iyi için kurban edilmekten emin olmalılar. ${ }^{8}$ Rawls bu şekilde herkese eşit siyasal özgürlük ve hakların verilmesi ve hakkın iyiye önceliği prensibi ile topluluğun iyi anlayışına karşı hakları öncelemesi ile bireysel hakları savunmakta, grup haklarını ise desteklememektedir. Makul dini doktrinler ile seküler doktrinlere sahip vatandaşların, farklılaşmış haklarla değil, üzerinde örtüşen görüş birliğine vardıkları toplumsal adalet ilkeleri çerçevesinde, bireysel haklar temelinde bir arada yaşamalarının mümkün olduğunu ortaya koymaktadır.

Liberal görüşle benzer şekilde, cumhuriyetçi teori de bireysel hakları benimser. Kimlik temelli, kültürel, dini, etnik grup hakları, devletin tarafsızlık idealine aykırıdır. ${ }^{9}$

Katılımcı, genişlemeci (expansive) bir cumhuriyetçi demokrasi anlayışına sahip olan Jürgen Habermas da bu doğrultuda, bireysel hakları savunmakta grup haklarını savunan yaklaşıma karşı çıkmaktadır. Habermas'a göre, 'tam anlamıyla özümsenmiş bir haklar teorisi kültürel farklılıkların taleplerini görmezden gelmez'. Bu nedenle, yapılması gereken, farklı gruplara farklı haklar tanıyarak

5 John Rawls, Siyasal Liberalizm, çev. Mehmet Fevzi Bilgin (İstanbul: İstanbul Bilgi Üniversitesi Yayınları, 2007), 51.

6 Rawls, Siyasal Liberalizm, 51.

7 Rawls, Siyasal Liberalizm, 68-70.

8 Akt. Alan Ryan, "John Rawls", çev. Ahmet Demirhan, Çağdaş Temel Kuramlar, drl. Quentinne Skinner (İstanbul: İletişim Yayınları, 2013), 141-142.

9 Ayhan Kaya-Turgut Tarhanlı, "Giriş: Türkiye'de Azınlıklar ve Anayasal Yurttaşlık”, Türkiye'de Çoğunluk ve Azınlık Politikaları: AB Sürecinde Yurttaşık Tartışmaları, drl. Ayhan Kaya-Turgut Tarhanlı (İstanbul: Tesev Yayınları, 2. Baskı, 2006), 14-15. 
sisteme tamamen yabancı bir uygulamaya gitmek değil, haklar teorisinin iç dinamiklerini çalıştırmaktır. Haklar teorisinin özel özerklik ve kamusal özerkliği temin eden yapısı, vatandaşların kendilerine hak ve özgürlükler tanıyan bir hukukun hem muhatapları hem de yazarları olduklarının idrakinde olmalarını vurgular. Dolayısıyla, vatandaşların yasa yapma süreçlerine, sahip oldukları farklı fikirlerini sunabildikleri iletişim biçimleri olduktan ve bunun için gerekli düzenlemeler yapıldıktan sonra, bireylerin kimliklerini oluşturan yaşam bağlamlarının da korunduğu, kültürel hakların da dile getirildiği bir ortam söz konusu olacaktır. ${ }^{10}$ Buradan hareketle şunu söylemek mümkündür: Dindarların ve farklı kimliklere sahip insanların, yaşam biçimleri doğrultusunda eşit haklara sahip olarak yaşaması, dini kimlikleri nedeniyle ayrımcılığa uğramamaları, bireysel haklarla temin edilebilir. Dindarların kişiliğini, kimliğini belirlemede etkili olan dini kültürün korunması ve yeniden üretilmesi için gerekli olan toplanma özgürlüğü, din eğitimi, dini ibadet özgürlüğünü sağlayan kültürel haklar, kolektif haklar/grup hakları olarak değerlendirilmemelidir. Aksine, dini kimliğinden dolayı dışlanmayı ortadan kaldıran, vatandaşlığa alınmayı garantileyen öznel haklar ile ayrımcılık ortadan kaldırılır ve vatandaşın kimliğini oluşturan ortamlar korunabilir. ${ }^{11}$ Öte yandan, Habermas'a göre, kolektif haklar hem gruplar arası eşitsizlik duygusu oluşturabilir hem de grup üyelerinin bireysel özgürlüklerinin ihlal edilip, baskıya uğramalarına yol açabilir. ${ }^{12}$

Partikülarist yaklaşımı benimseyen ve topluluk haklarını savunan kanadın temsilcilerinden, liberal komüniteryan Charles Taylor ise konuya "tanınma" meselesi olarak yaklaşmaktadır. Taylor, liberal evrenselci yaklaşımın vatandaşlar arasındaki eşitliği sağlamak için dini-etnik-kültürel kimliklerindeki farklılaşmayı yok saydığını ve eşitlik için vatandaşların farklılıklarını görmezden gelen bir yaklaşım geliştirmenin de bir eşitsizlik ürettiğini ileri sürmektedir. Çünkü ayrımcılık yapmamak için tüm farklılıkların üstünü örterek tek bir kimlik, vatandaşlık kimliği ile vatandaşları tanımlamak, farklı dini-kültürel-etnik kimliklerin farklı ihtiyaçlarını görmezden gelerek onların dezavantajı pozisyona düşmelerine sebep olmaktadır. Taylor, farklılaşma politikalarının yaklaştığı gibi meseleye yaklaşmakta ve farklı dini kimliklerin öncelikle tanınması ve sonrasında kendilerine özgü kimlik, ihtiyaç ve taleplerine göre farklılaştırılmış muamele yapılmasının gereğini savunmaktadır. ${ }^{13}$

10 Jürgen Habermas, "Demokratik Hukuk Devletinde Tanınma Mücadelesi", çev. IIlknur Aka, "Öteki" Olmak, "Öteki”yle Yaşamak: Siyaset Kuramı Yazıları, Jürgen Habermas (İstanbul: Yapı Kredi Yayınları, 6. Baskı, 2012), 115-125.

11 Jürgen Habermas, Doğalcılık ve Din Arasında: Felsefi Denemeler, çev. Ali Nalbant (İstanbul: Yapı Kredi Yayınları, 2. Baskı, 2012), 253-256.

12 Jürgen Habermas, Between Naturalism and Religion: Philosophical Essays, çev. Ciaran Cronin (Cambridge: Polity Press, 2008), 297.

13 Charles Taylor, "The Politics of Recognition", Multiculturalism: Examining the Politics of Recognition, ed. Amy Gutmann (Princeton: Princeton University Press, 1994), 43-44. 
Çokkültürlü vatandaşlık anlayışı ile Will Kymlicka ise, evrensel insan haklarının vatandaşların hak ve özgürlüklerini koruma konusunda oldukça önemli olduğunu vurgulamakla ve liberal teoriyi kabul etmekle birlikte, farklı dini, kültürel kimliğe sahip grupların haklarını koruma noktasında yeterli olmadığı görüşündedir. Bu nedenle, farklı grupların ihtiyaçlarına göre farklı uygulamaların, farklı hakların tanınmasının önemini vurgulamaktadır. Kymlicka'nın, bizim konumuzla yakından ilişkili olan polietnik haklar yaklaşımı önemlidir. Polietnik haklar kategorisinde, en tartışmalı talepler, etnik grupların dini pratiklerini yerine getirmek için yasalar ve düzenlemelerden muafiyet talepleridir. Kymlicka, İngiltere'deki Yahudi ve Müslümanların Pazar gününü resmi tatil olarak belirleyen mevzuattan; Kanada'daki Sih erkeklerin, dini bir kıyafet olan türbanı takabilmek için hem zorunlu motosiklet kaskı uygulamasından hem de güvenlik güçlerinin resmi kıyafet uygulamasından; ABD'de Yahudilerin askerlikte yarmulke ${ }^{14}$ takabilmek için askeri üniformadan ve Fransa'daki Müslüman kızların başörtüsü takabilmek için resmi okul kıyafetinden muafiyet taleplerini bu taleplere örnek olarak vermektedir. Kymlicka, bu tür polietnik hakları, diğer kolektif haklardan ayırmaktadır. Evrenselcilerin eşitlik ilkesini ihlal edecekleri ya da ana akım toplumdan ayrılma ve gettolaşmaya yol açacağını iddia ettikleri polietnik haklar, diğer kolektif haklardan farklı olarak, etnik, dini grupların büyük topluma, çoğunluğa entegrasyonunu teşvik edecektir. ${ }^{15}$

Çoğu liberal, bireysel haklar-gruba özgü haklar ikileminde, gruba özgü haklar ile bir etnisitenin veya bir kültürün, dolayısıyla bir dinin hayatta kalması için müdahalede bulunmasının devletin tarafsızlığına aykırı olduğunu ileri sürmektedirler. Kültürel bir pazar söz konusudur ve bu kültürel pazara devlet müdahale etmemelidir. Burada zaten tüm vatandaşların, istedikleri yaşam tarzını, dini seçebilme hakkı vardır, istedikleri gibi birlik (association) kurup, ona üye toplayabilirler. Yani kendi kültür ve dinlerini yaşamak için gerekli olan her şey genel vatandaşlık haklarında mevcuttur. Kymlicka, buna karşı çıkmaktadır. Çünkü devletler, diller, sınırlar, resmi tatiller, semboller gibi konularda kaçınılmaz olarak, özel bir etnik, dini, ulusal grubun ihtiyaçlarını ve kimliklerini dikkate almak durumundadırlar. Böylelikle, devlet, kaçınılmaz olarak belirli kimlikleri teşvik ettiği için diğer kimlikler dezavantajlı duruma düşmektedir. Mesela, resmi tatil günleri Batılı ülkelerde Hıristiyanların ihtiyaçlarını karşılamaktadır. Bu durumda, örneğin Yahudiler ve Müslümanlar dezavantajlı pozisyona düşmektedirler. Dolayısıyla, devletin burada, Yahudi ve Müslümanların Pazar gününün tatil olması uygulamasından (Sunday closing laws/legislation) muaf olmasına izin vermesi, devletin tarafsızlığının ihlali değil, eşitlik ilkesi gereği, zorunlu bir durumun ortaya çıkardığı dezavantajı ortadan kaldırarak eşitliği sağlaması anlamına gelir.

14 Yahudi erkeklerin ibadet esnasında veya gündelik hayatta taktıkları takke, kipa.

15 Will Kymlicka, Multicultural Citizenship: A Liberal Theory of Minority Rights (Oxford: Oxford University Press, 2003), 30-31. 
Kymlicka, bu nedenle gruba özgü haklar ve çokkültürlü vatandaşlığın gerekliliğini vurgular. ${ }^{16}$ Burada dikkat edilmesi gereken şey, liberallerin de dikkat çektiği üzere, grubun, bu hakları içerde kendi üyelerine karşı baskılama aracı olarak kullanmaması, bu hakların toplum içerisindeki grup çeşitliliğini bozmaması ve bir gruba diğeri üzerinde baskı kurma fırsatı vermemesidir. ${ }^{17}$

Kymlicka ile benzer şekilde grup haklarını savunan Young ise, baskı kavramı üzerine yoğunlaşmıştır. Vatandaşlığa dair evrenselci yaklaşımı savunanların, grupların kendilerine has özelliklerini, kimliklerini yok sayarak, vatandaşığın belirlenmesi gerektiğine dair yaklaşımlarının, belli grupların baskılandığı bir sisteme yol açtığını ileri sürmektedir. Young, bu baskıyı engellemek için farklılaştırılmıs vatandaşı yk yaklaşımını önermektedir. ${ }^{18}$ Kymlicka'nın da belirttiği gibi, bu yaklaşım, belli grupların üyelerinin politik topluma sadece bireyler olarak değil, grupları aracılığıyla dahil olmaları ve haklarının kısmen grup üyeliklerine bağlı olması gerektiğini vurgulamaktadır. ${ }^{19}$

Görüldüğü üzere burada ele aldığımız görüşlerin tümü, çokkültürlü demokratik toplumlarda vatandaşların dini kimlikleri nedeniyle toplumda dezavantajı duruma gelmelerini engellemenin yollarını aramaktadırlar. Ancak sundukları çözüm önerileri birbirlerinden ayrışmaktadır. Evrensel, bireysel haklar, dini kimliklerden dolayı dışlanma veya avantajlı konuma geçmeyi engellemek, bireyi grup baskısından korumak, eşitlik ve özgürlüğü temin etmek için herkes için aynı hakları öngörmekte ve bu şekilde politik topluluğa katılımı sağlamaktadır. Buradaki sorunlardan biri, geçmişte, çoğunluk kültürüne göre zorunlu olarak şekillenmiş olan resmi düzenlemelerin farklı dinlere mensup insanların ihtiyaçlarına uymaması ve onların dini ibadet özgürlüğünü kısıtlamasıdır. İkincisi ise, kamusal kültürün/siyasal kültürün çoğunluk tarafından domine edilerek azınlıkta kalan dinlerin dezavantajı konuma düşmeleridir. Bunu önlemek için Rawls ve Habermas'ın kamusal akıl yürütme/kamusal siyasal tartışmalara katılma konusundaki önerileriönemlidir. Kolektif haklara baktığımızda ise, bireysel haklara dayalı, evrensel özgürlük ve eşitlik anlayışının eksikliklerini gidermek için ortaya atılmakla birlikte, yeni muhtemel sorunları içerisinde barındırdığını görmekteyiz. Sorunlardan birincisi, hakların, özgürlüklerin gruplara göre farklılaşması ile birlikte gruplar arasında ya da vatandaşlar arasında eşitsizlik duygusunun oluşmasıdır. Íkincisi ise, gruplara tanınan özel hakların grupların kendi üyelerinin bireysel haklarını kısıtlamada destekleyici bir rol oynamasıdır. Üçüncü sorun ise, her gruba farklı hakların tanınması ile grupların içine kapanması, gettolaşma ve ortak kamusal/siyasal kültürün ortadan kaybolması sorunudur.

16 Kymlicka, Multicultural Citizenship, 107-108; 114-115.

17 Kymlicka, Multicultural Citizenship, 152-153.

18 Iris M. Young, “Polity and Group Difference: A Critique of the Ideal of Universal Citizenship", Ethics, 99/2 (1989), 251.

19 Will Kymlicka, "Citizenship", Routledge Encyclopedia of Philosophy: Brahman - Derrida, Jacques, ed. Edward Craig, (London: Routledge, 1998), 2/364. 


\section{Kamusal Alan-Özel Alan}

Dinin kamusal taleplerine dair ele alacağımız ikinci problemli konu kamusal alan-özel alan konusudur. Antik Yunan'dan günümüze vatandaşlık için merkezi bir pozisyonda bulunan, vatandaşık pratiğinin icra edildiği alana tekabül eden kamusal alan, merkezi pozisyonunu yitirmeye başlamıştır. Jürgen Habermas'ın Kamusalığın Yapısal Dönüşümü çalışması bu noktaya işaret etmektedir. Kamusalın ortadan kalkması ya da kamusal alana katılımın önemsenmemesi, vatandaşlığın aktif bir vatandaşlıktan pasif bir vatandaşı̆̆a dönüşmesi anlamına geldiğinden, günümüz çokkültürlü toplumlarında kimlik temelli hak taleplerinin politikalarda etki yaratabilmesi, karşılık bulabilmesi noktasında vatandaşlık teorileri kamusal alanın çoğulcu bir biçimde yeniden yapılandırılmasının önemini vurgulamaktadırlar. Dine dayalı kimliğe sahip vatandaşlar, diğer kimliklerde olduğu gibi, kamusal alanın şekillenişine kendi bakış açılarıyla katkıda bulunmak ve kamusal alanda kendi dini ritüellerini, pratiklerini, kıyafetlerini kısacası din ile şekillendirilmiş kültür ve yaşam tarzlarını sürdürebilmek için birtakım taleplerde bulunmaktadırlar. Bu taleplerin karşılanmaması dini kimliğe sahip olan vatandaşların özel alana hapsolması anlamına gelir ki, sekülerleşme teorilerinin radikal yorumlarında bu bir öngörü olarak vardır. Ancak Jose Casanova'nın Modern Dünyada Kamusal Dinler çalışmasında vurguladığı gibi, dinin özel alana hapsolması ve kamusal alandan tamamen çıkarılması henüz söz konusu değildir.

Incelediğimiz teoriler kamusal alanda çoğulculuğa saygı duyulması konusunda hemfikir olmakla birlikte, kamusal alana katılımın vatandaşlığın bir gereği, yükümlülüğü olup olmadığı konusunda ayrışmaktadırlar. Cumhuriyetçi teori, kamusal alana katıımı vatandaşlığın olmazsa olmaz şartlarından biri olarak görürken, liberal teori daha çok özel alanı önceler, kamusal alana katılımı merkezi bir yere yerleştirmez. Önemli olan kişinin kendi iyi yaşam anlayışını sürdürebilmesi, amaçlarının peşinden gidebilmesidir. Bu noktada kamusal alana katılım kişinin tercihine kalmış bir meseledir. ${ }^{20}$ Bununla birlikte, liberal gelenekten gelen John Rawls'un teorisinde kamusal alan düşüncesi ve onun önemi, "kamusal akıl" kavramılla gündeme getirilir. Rawls'a göre, demokratik bir toplumda, farklı yaşam biçimlerinin, farklı dinsel, felsefi, ahlaki doktrinlere mensup vatandaşların adil bir şekilde bir arada yaşayabilmelerini tesis edecek siyasal bir adalet anlayışının ilkelerini ortaya koymak gerekir. Bu adalet anlayışı vatandaşların ortak, kamusal aklını ifade eder. Anayasal ilkeler ve temel adalet meseleleri ile ilgili vatandaşların akıl yürütme biçimidir kamusal akıl.21 Müzakereci demokrasi anlayışını benimseyen Rawls, kamusal tartışmayı demokrasi için oldukça önemli bulmaktadır. ${ }^{22}$ Bu nedenle, hem dini doktrinleri hem de din dışı doktrinleri

20 Lister-Pia, Citizenship in Contemporary Europe, 11-12.

21 Rawls, Siyasal Liberalizm, 55-56.

22 John Rawls, Halkların Yasası ve "Kamusal Akıl Düşüncesinin Yeniden Ele Alınması", çev. Gül Evrin (İstanbul: İstanbul Bilgi Üniversitesi Yayınları, 2. Baskı, 2006), 151-152. 
benimseyen vatandaşların, kendi doktrinlerine dayalı görüşlerinin siyasal gerekçelerini ortaya koydukları sürece kamu siyasal tartışmasına her zaman katılabileceklerini, orada kendi görüşlerini ifade edebileceklerini iddia etmektedir. Dolayısıyla Rawls, dindarların kendi dini doktrinlerine dayandırdıkları görüşleri ile kamu siyasal tartışmasına katılımlarında özgür olduklarını belirtmekte, ancak zamanı geldiğinde, bu görüşlerinin uygun siyasal gerekçelerini, nedenlerini sunmalarını şart koşmaktır. Bu siyasal gerekçe sunma şartını proviso (sözleşme koşulu) olarak adlandırmaktadır. Görüşlerin ifade biçimi ile ilgili herhangi bir sınırlandırma ise söz konusu değildir. ${ }^{23}$

İnsanların ancak toplum içerisinde, toplumsallaşma süreçleriyle bireyleşeceği, toplumsal doğaları gereği birbirlerine bağımlı oldukları görüşünden hareketle, Habermas da kamusal alanı oldukça merkezi bir yere yerleştirir ve müzakereci demokrasi anlayışını benimser. Ona göre, belirli bir siyasi kültürün oluşması ve demokratik ilkelerin vatandaşlarca benimsenmesi için canlı ve söylemsel bir kamusal alan zaruridir. Antik Yunan'daki gibi yüz yüze ilişkilerin olmadığı ve karmaşık, çeşitli, çoğulcu toplumlarda vatandaşlar arasında bir bütünleşme, onları bir arada tutma, toplumsal entegrasyon ancak hukuk aracılığıyla soyut bir dayanışma üretilerek sağlanabilir. Bu dayanışmanın üretilmesi ve sürdürülmesinde, toplumsal bütünleşmenin yapılarını ortaya çıkaran kamusal alan ve bu alana katılım oldukça önemlidir. Habermas, anayasal demokratik devletin normatif temellerini meşrulaştırma ve vatandaşlar arasındaki toplumsal bütünleşmeyi sağlama noktasında dine ihtiyaç duyduğu görüşüne katılmamakla, liberal bir devletin anayasasının meşrulaştırma ihtiyacının, dinden bağımsız olarak karşılanabileceğini düşünmekle birlikte, küresel ekonomi ve küresel toplumun denetlenemeyen dinamiklerinin, demokratik bağları ve ihtiyaç duyulan vatandaşlar arası dayanışmayı aşındıran, parçalayan etkilerinin de tamamen göz ardı edilemeyecek boyutta olduğunu kabul etmektedir. Ona göre, bu noktada anayasal devletin, vatandaşların norm bilinci ve dayanışmasını güçlendiren kültürel kaynaklara, dolayısıyla dine eğilmesi yararlı olacaktır. ${ }^{24}$ Buradan hareketle, Habermas daha önce çalışmalarında yer vermediği din fenomenine, küreselleşme süreçleri nedeniyle yer vermeye başlamış ve seküler devlet modeline ve sekülerleşmenin ana tezlerine bağlı kalmakla birlikte dini görüşlerin de hakikat içerebileceklerini ve kamusal tartışmalarda yer alma haklarının olduğunu savunmuştur. Bu doğrultuda "post-seküler toplum" fikrini öne sürmüştür. Post-seküler toplum görüşü, Jose Casanova'nın vurguladığı gibi ne modern toplumların yeniden eksen öncesi toplumlarda olduğu gibi kutsal bir içsel çerçeveye sahip olması (resacralisation/ reenchantment), ne de bireyler veya toplumların dindarlaşması, sekülerizasyon sürecinin tersine

23 Rawls, Halkların Yasası ve "Kamusal Akıl Düşüncesinin Yeniden Ele Alınması", 165-169.

24 Habermas, Doğalcllık ve Din Arasında, 99-109. 
çevrilmesi (desekülerizasyon) gibi bir toplumsal dönüşümü ima etmemektedir. ${ }^{25}$ Casanova'ya göre, Habermas, dini primitif, geleneksel, toplumsal gelişmenin geride kalmış bir aşamasına ait bir olgu olarak gören bir bakış açısı olan "sekülerist sekülerite" ve "stadial teori"deki bir değişimi kastetmektedir. Yani toplumsal bir dönüşümü değil, bilinçteki, dine bakıştaki bir değişimi, sorgulamayı dile getirmektedir. ${ }^{26}$

Post-seküler toplum anlayışından hareketle, Habermas, devletin her vatandaşın eşit özgürlüğünü garanti altına almada dünyagörüşsel olarak tarafsız olması fikrinin, sekülerist dünya görüşünün toplumun tüm alanlarına genişletilmesi anlamına gelmesini yanlış bulduğunu ifade eder. ${ }^{27}$ Habermas bu doğrultuda, vatandaşlık ve dinin kamusal alandaki yerine dair kurumların kamusallığı ile gayri resmi kamusallık arasında bir ayrıma gider. Buna göre, meclis, bakanlıklar, mahkemeler ve yönetimler gibi resmi kamusal kurumlar sekülerdir ve buralarda yalnızca seküler gerekçeler geçerlidir. Bunu dindarlar da dahil olmak üzere herkes bilmeli ve kabul etmelidir. Dolayısıyla, bu kurumlarda dindarların dini görüşleri, gerekçelendirmeleri ancak seküler dile tercüme edilerek geçerli olabilir. Ancak burada dikkat edilmesi gereken, dindarların bu nedenle politik karar süreçlerine yabancılaştırılmaması ve kimliklerini kamusal ve özel olarak parçalamak zorunda bırakılmamasıdır. Dindarlar siyasal anlaşmazlık durumlarında, kamusal tartışmalara kullandıkları tek dil, dini dil dahi olsa katkıda bulunabileceklerini bilmeli ve diğer vatandaşlarla aynı şekilde, yasaların muhatapları oldukları gibi, yapıcıları da oldukları bilincine sahip olmalıdırlar. Dini görüşlerin seküler dile tercümesi işi de yalnızca dindarların değil aynı zamanda seküler vatandaşların vazifesi olmalıdır. Gayri resmi kamusal alan ise, dindar vatandaşların görüşlerini dini dil ile ifade etmekte özgür oldukları bir alana işaret eder. ${ }^{28}$ Habermas, resmi kamusal kurumlarla, gayri resmi kamusal iletişim ve karar alma süreçleri arasında kurulacak olan filtreleme sistemi ile Rawls'un proviso yaklaşımının dindar vatandaşların üzerine yüklediği asimetrik yükün ortadan kaldırılacağını iddia etmektedir. ${ }^{29}$ Çünkü Habermas'ın önerisinde, resmi kurumların tartışma süreçlerine aktarılacak dini görüşlerin tercüme işi yalnızca dindarların sorumluluğunda değildir, tüm vatandaşların sorumluluğundadır. Yine bu doğrultuda, kurumsal düzeyde tarafsızlık adına sekülerliği savunan liberal devlet, inananların siyasi tavırlarının da dinden bağımsız olmasını bekleyemez. Habermas, bunun yalnızca devlet kurumlarında tarafsız olmaları gereken, politikacılar, kamusal makamlarda çalışanlar veya buna aday olanlardan

25 José Casanova, "Exploring the Postsecular: Three Meanings of "the Secular" and Their Possible Transcendence", Habermas and Religion, ed. Craig Calhoun vd. (Cambridge: Polity Press, 2013), 30-31.

26 Casanova, "Exploring the Postsecular", 32-33.

27 Habermas, Doğalcılık ve Din Arasında, 110-111.

28 Habermas, Doğalcılık ve Din Arasında, 125-129.

29 Jürgen Habermas, "The Political": The Rational Meaning of a Questionable Inheritance of Political Theology", The Power of Religion in the Public Sphere, ed. Eduardo Mendieta-Jonathan VanAntwerpen (New York: Columbia University Press, 2011), 25-26. 
beklenebileceğini ileri sürmektedir. Mesela, dindar bir vatandaşın oyunu dini görüşlerinden tamamen bağımsız olarak kullanması beklentisi, bireyin kimliğini, varoluşunu şekillendiren bağlılıklarının, kimliğinin bütünlüğünün tamamen göz ardı edilmesi anlamına gelir. Dini yaşam biçimlerini korumak gayesinde olan liberal devlet, siyasi kamuoyunda, dindar vatandaşlarına dini ve seküler gerekçeler arasında ayrım yapma yükümlülüğünü yüklememelidir. ${ }^{30}$

Liberal komüniteryan bir bakış açısına sahip olan Charles Taylor, meseleyi Batı'da dine dair yaklaşımla ilişkili olarak ele almaktadır. Ona göre, Aydınlanma ve sekülerizmin yanlış bir yorumundan dolayı dini argümanların kamusal alanda bir sınırlandırmaya tabi tutulmasına yönelik bir yaklaşım söz konusudur. Din ve liberal devlet arasındaki geçmişteki çatışmaların ortaya çıkardığı dine dair düşmanca veya dini bir sorun gibi algılama yaklaşımının izleri hala devam etmektedir. Yine Aydınlanma'nın dinin insan işlerinin bir kaynağı olduğu dönemden çıkılıp, vahiyden akla bir geçişin yaşandığı, bir kırılma olduğuna dair düşüncenin epistemolojik bazı sonuçlarısözkonusudur. Buna göre, dine dayandırılan düşünce, saf bir şekilde seküler akıl yürütme eyleminden daha az rasyonel kabul edilmekte, akletmenin hatalı bir versiyonu olarak değerlendirilmektedir. Taylor, Rawls ve Habermas gibi düşünürlerde de bu yaklaşımın izlerinin olduğunu iddia eder. Dini olmayan bir biçimde enforme edilen, dine dayanmayan salt akıla (reason alone) özel bir statü verirler. Salt akıl, moral politik meseleleri meşru olarak herkesi tatmin edecek şekilde çözebilme kabiliyetine sahipken, dine dayandırılarak üretilen sonuçlar, düşünceler her zaman şüphelidirler ve yalnızca kendi inananlarını ikna edebilirler. Taylor'a göre, Rawls'un ve Habermas'ın önceden savundukları ve şimdi vazgeçtikleri şu görüşlerin arkasında da yatan bu bakış açısıdır: Rawls, önceden, dindar vatandaşların, sadece mensup oldukları dinin takipçilerini ikna edebilecek olan dini dili kamusal alanın girişinde bırakarak, herkesin makul olarak kabul edebileceği akıl dilinde müzakereye katılabileceklerini savunuyordu; Habermas ise, seküler aklın, demokratik devletin meşruiyetinin sağlanması ve bizim politik etiğimizi tanımlamada ihtiyaç duyduğumuz normatif sonuçlara varmamız için yeterli olduğunu düşünüyordu. Taylor'a göre, Habermas bu görüşünü revize etmiş olsa da, devletin resmi kurumlarında yine de seküler dilin kullanılması gerektiğini, dini referansların çıkarılması gerektiğini savunması, onun söz konusu bakış açısını bir anlamda devam ettirdiğini göstermektedir. ${ }^{31}$ Taylor'a göre, Rawls ve Habermas, seküler bir devlette, kullanılan dilin nötr olmak zorunda olduğu alanların olduğunu düşünmektedirler. Taylor, bu alanların vatandaşların kamusal alandaki müzakerelerini veya yasamadaki müzakereleri içermemesi gerektiğini iddia etmektedir. Ona göre, seküler olması ya da nötr olması gereken alan, devletin resmi dilidir. Yasama, mahkeme kararları ya da idari kararlar bu dilde

30 Habermas, Doğalcllık ve Din Arasında, 125-129.

31 Charles Taylor, "Why We Need A Radical Redefiniton of Secularism”, The Power of Religion in the Public Sphere, ed. Eduardo Mendieta-Jonathan VanAntwerpen (New York: Columbia University Press, 2011), 48-53. 
ifade edilmelidir. Parlamento'daki bir yasa ne İncil'e referans veren bir cümle ile ne de Kant ya da Marx'ın görüşüne referans veren bir cümle ile meşrulaştırılamaz, ifade edilemez. Bu da, devletin tarafsız olması ile ilgilidir, din dilinin doğası ile ilgili değildir.32

Rawls ve Habermas'ın dinin kamusal alana katılımına dair görüşlerini eleştiren bir başka isim ise, radikal demokrasiyi, agonistik çoğulculuğu savunan Chantal Mouffe'dur. Mouffe'a göre, agonistik çoğulculuk, kapsamlı görüşlerin kamusal alandan dışlanmasını gerektirmediği için, dindarlara kamusal alanda müzakereci demokrasi anlayışından daha çok yer açar. Müzakereci demokrasinin hem kamusal alanda rasyonel bir fikir birliğine varmayı amaçladığı hem de kamusal/ siyasal tartışmalarda yalnızca evrenselleştirilebilir görüşlere yer verdiği için, dini düşüncelerin katılımına açık olmadığını, dini özel alan meselesi olarak gördüğünü iddia etmektedir. Mouffe'a göre, hem Habermascı hem de Rawlscu versiyonlarında farklı şekillerde de olsa dini argümanlar siyasetin dışında bırakılırlar. Bunun aksine, agonistik çoğulculuk ise, dini kimlik biçimlerinin siyasi eylem için meşru güdüler olduğunu kabul ettiği için onları kamusal alanın dışında bırakmaz. Dini gruplar, dindar vatandaşlar, anayasal ilkeleri kabul ettikleri sürece agonistik tartışmalarda, yer alabilirler. Kamusal alana dahil olabilirler. ${ }^{33}$ Mouffe dinin kamusal alandan dışlanmasının, kilise-devlet, din-politika ve kamusal-özel ayrımının birbirini gerektirdiği varsayımından kaynaklandığını ileri sürmektedir. Oysa kilise-devlet ayrımı dinin özel alana indirgenmesini ve dini sembollerin kamusal alandan çıkarılmasını gerektirmez. Dindar vatandaşlar, dini gruplar, siyasal alana, oradaki tartışmalara katılabilirler. Hatta geçmişe bakıldığında birçok toplumsal adalet mücadelesinin dini güdülerle yürütüldüğünü görmek mümkündür. ${ }^{34}$

Grup-farklılaştırılmış vatandaşıı anlayışını geliştiren Iris M. Young ise, heterojen kamu fikri ile kamusal alanı yeniden yorumlar. Ona göre, evrensel vatandaşlık anlayışının kamu fikri de partikülariteye karşı genelliği, farklılıklara karşı ortaklığı temsil ettiği için dezavantajı grupları dışlamaya meyillidir. Eşit vatandaşlık statüsüne sahip olsalar bile, evrensel vatandaşlığa dayalı bir kamu anlayışı homojenliği kamusal katılımın bir şartı yapacağından, farklılıklara sahip insanların partiküler çıkarlarını, perspektiflerini, görüşlerini aşan bir tarafsız bakış açısı benimsemeleri gerekeceğinden ve bunun imkansız olması nedeniyle farklı kimliklere sahip vatandaşlar dezavantajlı pozisyona düşeceklerdir. Çünkü farklı grupların, farklı deneyimleri, farklı toplumsal bağlılıkları, ihtiyaçları, kültürleri olduğu için politik meselelere bakış açılarının bunlardan etkilenmemesi imkansızdır. Ayrıca baskın olan, çoğunlukta olan grubun böyle bir kamuyu

32 Taylor, "Why We Need A Radical Redefiniton of Secularism", 50.

33 Chantal Mouffe, "Religion, Democracy, and Citizenship", Political Theologies: Public Religions in a Post-Secular World, ed. Hent de Vries-Lawrence E. Sullivan (New York: Fordham University Press, 2006), 326.

34 Mouffe, "Religion, Democracy, and Citizenship", 325. 
domine etme riski her zaman söz konusudur. Young, buna karşın evrensel vatandaşlık yerine, grup-farklılaştırılmış vatandaşlığı, homojen kamu yerine heterojen bir kamu fikrini çözüm olarak sunmaktadır. Heterojen bir kamusal alanda, farklılıklar kamusal olarak tanınır ve farklılıkların özel alana indirgenemez ya da yok edilemez olduğu kabul edilir. ${ }^{35}$ Young'a göre, demokratik bir kamu, baskı görmüş ya da dezavantajlı gruplara, etkili tanınma ve temsil mekanizmaları sağlamalıdır. Bu mekanizmalar, baskı her zaman söz konusu olacağı için de geçici değil, kalıcı olmalıdır. ${ }^{36}$ Meseleye din açısından baktığımızda, Young'ın heterojen kamusu, dini grupların da kendi taleplerini, grup temsil mekanizmaları ve gruba özgü vatandaşlık ve haklar yolu ile ortaya koyabilecekleri bir ortamın yolunu açar gözükmektedir.

Yukarıdaki tartışmada görüldüğü üzere ele aldığımız vatandaşlık teorileri, dinin kamusal alana katılımını artık demokrasinin bir gereği olarakgörmektedirler. Dinin özel alana hapsolmasını, kamusal alana söyleyeceği bir şey olmadığını savunan bir yaklaşım olmamakla birlikte, koşullu bir katılım öngörülmektedir. Rawls, dini argümanlar için uygun siyasal gerekçeler talep ederken (proviso), Habermas, dini argümanların resmi kamusal alanlara girebilmesi için tercüme filtresinden geçmesini şart koşmaktadır. Taylor, Mouffe ve Young kamusal alana katılımda herhangi bir ön şart belirlememekle birlikte, anayasal ilkelerin benimsenmesi (Mouffe), yasanın dilinin seküler olması (Taylor) gibi bazı çizgilere değinmektedirler.

\section{Anayasal ilkeler, Demokrasi ve Din}

Çalışmamızda, din ve vatandaşlıkla ilgili bir diğer mesele ise, demokratik anayasal bir sistem içerisinde, dindarların özel alanda da kamusal alanda da dine dayalı yaşam tarzlarını sürdürmeleri, din ve ibadet özgürlüğüne sahip olmaları ve kendi kimlik ve kültürlerini sürdürebilmelerinin şartlarıdır. Uygulamada her devletin yorum farklılıklarından meydana gelen birtakım farklar olsa da, anayasal demokratik devletler din ve vicdan özgürlüğünü garanti altına almaktadır. Bunun karşılığında beklenilen ise dindarların, vatandaşlar olarak anayasal ilkeleri ve demokratik rejimi benimsemesidir.

Meseleye liberal teori açısından baktığımızda, Rawls'un görüşleri önem arz etmektedir. Rawls, dine yaklaşımının, dinle (Katoliklik) çatışan Aydınlanmacı liberalizmden farklı olduğunu ileri sürmektedir. Demokrasi ve din arasında, dindarlaranayasalilkeleribenimseyip onlara göre hareket ettikleri sürece herhangi bir çatışmanın olmayacağını düşünür. Kilise-devlet ayrımını, yalnızca seküler kültürü korumak için benimsenmiş bir ilke olarak değil, aynı zamanda dinleri, din özgürlüğünü korumak için benimsenmiş bir ilke olarak değerlendirmektedir. Kamusal akıl-demokrasi-din ilişkisinde, anayasal devlet, diğer vatandaşlarının

35 Young, "Polity and Group Difference", 256-258.

36 Young, "Polity and Group Difference", 261-262. 
olduğu gibi dindar vatandaşlarının da bütün hak ve özgürlüklerini güvence altına almakla yükümlüdür. Bunun karşılığında beklediği ise, tüm diğer vatandaşlar gibi dindar vatandaşların da meşru yasaların getirdiği yükümlülükleri kabul etmeleridir. Dindar vatandaşlar, dinsel hakimiyetlerini kurmak veya kendi doktrinlerini etkin kılmak için anayasayı değiştirme gibi düşüncelerinden kesin bir şekilde vazgeçmelidir. Demokratik toplumu desteklemeyen, anayasal ilkeleri kabul etmeyen dini doktrinler Rawls'a göre makul değildirler, çünkü anayasal ilkeleri kabul etmeyerek karşılıklılık kriterini yerine getirmezler. Köktenci doktrinler bu kategoridedirler. Bu doktrinler, siyasal liberalizmin ilgi alanında değildirler. Hatta demokratik kurumlar için tehdit niteliğindedirler. ${ }^{37}$

Habermas da Rawls'a benzer şekilde, devletin herkese eşit inanç özgürlüğü sağlayabilmek için dünyagörüşsel olarak tarafsızlığının zorunlu olduğunu, bunun karşılığında vatandaşların ise din-devlet ayrılığı ilkesi gibi anayasal ilkeler üzerinde uzlaşmasının zorunlu olduğunu savunur. Ancak Habermas, mahkeme, meclis gibi resmi kurumların seküler olduğunun kabul edilmesi gerektiğini ancak, kurumsal düzeydeki bu sekülerliğin vatandaşların gayri resmi kamusal alandaki görüş ve tavırlarına genişletmenin, mesela oy kullanma gerekçelerine kadar genişletmenin aşırı sekülerist bir yaklaşım olduğunu ve devletin vatandaşından bunu bekleyemeyeceğini ileri sürmektedir. ${ }^{38}$ Habermas da köktendinci akımları, başka yaşam biçimlerinin yaşamasına izin vermeyen bir zihniyete sahip oldukları için kamusal alandan dışlar. Anayasal hukuk devleti ancak köktendinci olmayan, farklı yaşam biçimlerinin varlığını kabul eden yaşam biçimlerini hoş görebilir. ${ }^{39}$ Anayasal toplumda yaşayan dinlerin, farklı yaşam biçimlerinin varlığını kabul etmeleri gerekir. Bu çokkültürlü demokratik bir devletin bünyesinde yaşayan grupların da bireylerin de kabul etmesi gereken bir ilkedir. Bu da bizi ortak siyasi kültürü, anayasal ilkeleri benimsemenin gerekliliğine götürür.

Mouffe, bu konuda, devletin, bireysel özgürlük ve çoğulculuğa saygı için din ve ahlak meselelerine ilişkin agnostik olması gerektiğini vurgular. Ancak devlet, politik değerler konusunda agnostik olamaz, kendi etiko-politik değerlerini inşa etmek durumundadır. Modern demokrasinin, eşitlik, özgürlük, temel insan haklarına saygı, halkın egemenliği gibi ilkeleri, değerleri söz konusudur. Bu doğrultuda, kilise-devlet, sivil hukuk ve dini hukukta birtakım ayrımlara gidilmiştir. Bu şekilde bireysel özgürlük ve çoğulculuk garanti altına alınmıştır. Bunların kaldırılması talep edilemez. İşte bu noktada, Mouffe'un çoğulculuğunun sınırları çizilir. O, kültür, din, ahlak alanında olabildiğince geniş bir çoğulculuğu savunur. Ancak onun vatandaşlık anlayışı aynı zamanda, modern demokrasinin politik ilkelerine bağlılığı ve onun temel kurumlarını savunmaya sadakati

37 Rawls, Halkların Yasası ve "Kamusal Akıl Düşüncesinin Yeniden Ele Alınması", 161-169; 179-193.

38 Habermas, Doğalcılık ve Din Arasında, 125-127; Habermas, Between Naturalism and Religion, 128-130.

39 Habermas, "Demokratik Hukuk Devletinde Tanınma Mücadelesi”, 132-133. 
gerektirir. Bunu benimsemeyen farklılıkları, farklı grupları kabul edemeyeceğini vurgular. ${ }^{40}$

Çokkültürlü vatandaşlığı savunan, Kymlicka da diğer teorisyenlere benzer şekilde demokratik ilkelerin kabulünü şart koşar. Liberal demokrasiler, kültürel çeşitliliğin çoğunu kendisiyle bağdaştırabilse de hepsini bağdaştıramaz. Hoşgörünün birtakım sınırları vardır. Azınlık hakları için iki tür sınırlandırma söz konusudur: Birincisi, liberal ilkeler, azınlık kültürünün kendi üyelerinin temel sivil ve politik haklarını kısıtlamasını, yani iç kısıtlamaları meşru görmez. İkincisi, liberal ilkeler, dış koruma taleplerini uygun bulsa da, öngörülen grup hakları, gruplar arası eşitsizlik yaratmadığı takdirde meşrudurlar. Bu sınırlamalardan dolayı, bireysel özgürlük veya kişisel otonomi gibi prensipleri kabul etmeyen dini azınlık gruplarının taleplerini çokkültürlü vatandaşlık politikası karşılamaz. ${ }^{41}$ Çünkü dini hoşgörü, Batı'da, Din Savaşları sonucunda, Katolikler ve Protestanların ortak bir dine dayanmayan istikrarlı bir anayasal düzeni tanımalarıyla ortaya çıkmış ve Batı'da bireysel vicdan özgürlüğü fikrine dönüşmüştür. $O$ artık özgürce ibadet etme, kişinin kendi dininin propagandasını yapma, dinini değiştirme veya dinden çıkmak için temel bir bireysel haktır. Bu noktada, özgürlüklerden birinin bireysel kullanımının kısıtlanması, temel bir insan hakkının ihlali olarak görülür.42

Yukarıdaki değerlendirmelerden anlaşıldığı üzere, ele aldığımız vatandaşlık teorileri, dindar vatandaşlardan anayasal, demokratik düzen ve ilkeleri kabul etmelerini beklemektedir. Bireysel hak ve özgürlüklere saygı ile farklı kimliklerin yaşam haklarına saygı konusunda olumlu bir yaklaşım göstermelerini gerektirmektedirler. Bu koşulları taşımayan köktenci hareketler bu teorilerin kapsamı dışında kalırlar.

\section{Kimlik-Aidiyet-Din}

Dinin veya etnisite, kültür, ırk, vb. gibi farklı olguların kimliğin şekillenmesinde önemli bir rol oynadığı gerçeği dikkate alınmadan vatandaşlık tartışmalarının yürütülmesinin imkansız olduğu artık geniş ölçüde kabul edilmektedir. Bu bağlamda, ele aldığımız vatandaşıık teorilerinin dinin kimlik üzerindeki şekillendirici etkisine dair görüşlerinden hareketle din-kimlik-aidiyet meselesi tartışılacaktır.

Rawls, kişinin kendi kimliği üzerindeki kontrolünü ve seçimlerini vurgulayan bir yaklaşıma sahip olmasına rağmen, din, dil, etnisite gibi özelliklerin ve bu özellikleri taşıyan toplulukların varlığını yadsımamaktadır. Bu noktada önemli olanın, kişinin istediği takdirde, bu topluluklara ya da kimliklere artık kendini ait

40 Chantal Mouffe, "Preface: Democratic Politics Today", Dimensions of Radical Democracy: Pluralism, Citizenship, Community, ed. Mouffe Chantal (London: Verso, 2. Baskı, 1995), 11-13.

41 Kymlicka, Multicultural Citizenship, 152-153.

42 Kymlicka, Multicultural Citizenship, 155-156. 
hissetmediği durumlarda, özgür bir şekilde ayrılabilme ve yenilerine katılabilme noktasında tercih hakkını elinde bulundurabilmesi olduğunu vurgulamaktadır. ${ }^{43}$

Habermas'ın düşüncesinde ise, kişilerin ancak toplumsallaşarak bireyleştiği görüşü vurgulanmaktadır. Kişilik, kimlik özneler arası bir özellik taşır ve din, kültür gibi olgular tarafından şekillendirilir. Bu nedenle, vatandaşın kimliğinin bütünlüğü; kimliğini oluşturan ortamlar, kültürel ortamlara erişimi, kiş̧ilerarası ilişkilere ve geleneklere erişiminin sağlanması ile korunabilir. Bunu sağlayacak olan ise yukarıda değinildiği üzere, bireysel, öznel özgürlüklerdir. ${ }^{44}$ Öte yandan, Habermas, kimlik konusunda, kimliğin oluşumunda dinin ve başka olguların rolünü kabul etmekle birlikte, artık post-geleneksel bir toplum haline geldiğimizi, bu nedenle kimliklerin de post-konvansiyonel bir biçim almaları gerektiğine dair bir fikir ortaya koymaktadır. Buna göre, vatandaşların, partiküler geleneklerini, grup kimliklerini ortak evrensel prensipler ışığında eleştirel olarak düşünmeleri gerekir. Böylelikle, geleneklerini, kültürlerini, kimliklerini reflektif olarak ya tasdik ederler ya da reddederler. ${ }^{45}$ Post-seküler toplum fikrinde de dindar ve seküler vatandaşların sekülerizasyon süreçlerini ortaklaşa bir öğrenme süreci olarak değerlendirmelerini ve dindarların da sekülerlerin de kimliklerini, görüşlerini oluşturan dini veya seküler görüşlerine refleksif bir yaklaşım geliştirmelerini talep etmektedir.

Konuya liberal komüniteryan bir perspektiften yaklaşan Taylor ise, çokkültürlü toplumlarda farklılıkların tanınma talebi veya ihtiyacının öneminin kimlikle olan bağından kaynaklandığını vurgulamaktadır. Kimlik, kişinin, kendine ait temel tanımlayıcı özelliklerine dair anlayışına dayanır. Toplumda tanınmama ya da yanlış tanınma durumunda, bir kişi ya da gruba yönelik sınırlayıcı, aşağılayıcı, yanlış bir imaj oluşturulduğunda, bu bir baskıya dönüşebilir ve o kişi ya da gruba zarar verebilir. Bu nedenle, bir kimliğin doğru bir şekilde tanınması oldukça önemlidir. ${ }^{46}$ Öte yandan kimliğin oluşum süreci toplumsal bir süreçtir ve diyalojiktir. Herbert Mead'ın önemli ötekiler dediği kişilerle etkileşimler sonucunda kimlik oluşur. Taylor, kimliklerin bu şekilde toplumsal alanda ve açık diyalog içerisinde oluşan bir yapı arz etmesi nedeniyle eşit tanınmanın daha da önem kazandığını vurgulamaktadır. ${ }^{47}$ Bu doğrultuda sunduğu öneri, eğitim alanında, müfredat değişikliğidir. Çünkü Taylor'a göre eski müfredatlar, Avrupa kökenli erkeklerin değerliliği üzerine temellendirilmiştir. Dışlanan farklı grup ve kültürlere ilişkin görmezden gelme veya alçaltıcı imajların ortadan kaldırılması için müfredat değişikliği gereklidir. Taylor, vatandaşlar arasında özgürlük ve

43 André Berten vd. (ed.), Liberaller ve Cemaatçiler, çev. Başak Demir vd. (Ankara: Dost Kitabevi, 2006), 201-202.

44 Habermas, Doğalcılık ve Din Arasında, 254-255; Habermas, "Demokratik Hukuk Devletinde Tanınma Mücadelesi”, 116.

45 Jan-Werner Müller, Constitutional Patriotism (Princeton: Princeton University Press, 2007), 26-30.

46 Taylor, "The Politics of Recognition", 25-26.

47 Taylor, "The Politics of Recognition", 32-36. 
eşitliğin sağlanması, baskın grupların kendi hakimiyetlerini oluşturmak uğruna diğer grupları küçük düşürücü imajlara hapsetmelerine engel olmak, son vermek için çokkültürlü bir müfredat önermektedir. ${ }^{48}$

Taylor, sekülerizmin yanlış bir modeli veya anlayışından kaynaklı sorunların, dindar vatandaşların kamusal alana dahil olmalarında olduğu gibi, dini kimlik ve aidiyetle ilgili meselelerde de ortaya çıktığına dikkat çekmektedir. Sekülerizmi, devletin toplumun çeşitliliğine cevabı ile ilgili bir politika değil de; devletin dinle ilgili sorunları ile baş etme politikası olarak değerlendirmenin yanlış olduğunu vurgulamaktadır. Dini gruplara mümkün olduğunca tehdit gözüyle bakmamanın ve onları muhataplar olarak kabul etmenin önemine vurgu yapmaktadır. Taylor'a göre, sekülerizm politikalarının üç amacı olmalıdır: Birincisi, insanların kimliklerini, aidiyetlerini ve pratiklerini korumak. İkincisi, hepsine eşit muamelede bulunmak. Üçüncüsü ise, hepsini muhatap kabul etmek ve dinlemek. Dine dayalı kimlik, aidiyet, topluluk, seçim ve görüşler de bu kapsamdadır. Devletin tarafsızıı̆ı̆, dini ya da dini olmayan herhangi bir pozisyonu kayırmak ya da itibarsızlaştırmaktan kaçınmayı amaçlamaktadır. ${ }^{49}$

Taylor, Fransa'da başörtüsünün okulda öğrencilere yasaklanması, German Laender'de ise öğretmenlere yasaklanmasının kimlikle ilişkili iki farklı gerekçeye dayalı olduğunu ileri sürer. Fransa'da yasağın gerekçesi, öğrencilerin kendi tercihleri değil, ailelerin zorlaması nedeniyle bireysel özgürlüklere aykırı olması ve büyük simgelerin cumhuriyetin değerlerine bir meydan okuma olarak değerlendirilmesi iken, German Laender'de yasağın gerekçesi, kamu kurumunda yetkili olan birinin etiketlenmemiş olmasıdır. Taylor'a göre, Batı'da dine bir sorun olarak yaklaşmanın sonucu olarak, birinci olayda göçmen azınlıkların din özgürlüklerini sınırlandırarak, onların köklü ana akımla hiç bir zaman eşit statüde olamayacakları mesajını göçmenlere vermek ve ikinci olayda ise dini pratikleri nedeniyle etiketlenmiş olan kimselerin kamu kurumlarında yetkili kişi olamayacağı, otorite pozisyonlarından dışlanacağı mesajını gittikçe çeşitlenen bir toplumun çocuklarına vermek oldukça yanlış bir yaklaşımdır. ${ }^{50}$ Taylor, modern demokratik toplumlarda siyasi kimliğin oldukça önemli olduğuna ve bu kimliğin demokrasi, insan hakları, eşitlik gibi belirli prensiplerle veya bazen de dil veya dini geleneklerle tanımlandığını ileri sürmektedir. Bugün oldukça çeşitlenen toplum yapısında, geniş kapsamlı olarak bu tarihsel kimliklerin yeniden tanımlanması gerekmektedir. ${ }^{51}$ Buradaki tartışma, din özgürlüklerinin maksimize edilmesi ilkesi ile devletin tarafsızlığı ilkesi arasındaki gerilimden doğsa da, aslında devletin tarafsızığının ihlal edildiği düşüncesine götüren, farklı bir kimlik ve onun görünürlüğünün ana akım kimliğe karşıt ya da yabancı görülmesi ile de ilişkilidir.

48 Taylor, "The Politics of Recognition", 65-66.

49 Taylor, "Why We Need A Radical Redefiniton of Secularism", 36-37.

50 Taylor, "Why We Need A Radical Redefiniton of Secularism”, 41-42; 48-49.

51 Taylor, "Why We Need A Radical Redefiniton of Secularism", 45-46. 
Kimlik konusunda Mouffe'un yaklaşımı, hem komüniteryan hem de liberal özne anlayışlarından farklılaşmaktadır. Ona göre, liberallerin özne anlayışı topluluğu yok saydığı için, komüniteryanların özne anlayışı ise, yalnızca bir topluluğa ait olduğumuzu ve bu topluluğun bir iyi anlayışı etrafında birleştiğini savunmaları nedeniyle eksiktir. Her ikisi de özneye üniter bir varlık olarak yaklaşmaktadır. Halbuki çeşitli toplulukların üyeleri olduğumuz için, her zaman çoklu ve çelişkili öznelerizdir. ${ }^{52}$

Young ise kimlik konusunda birlik (association) ve grup arasında bir ayrışma üzerinden açıklama yapmaktadır. Birlik (association) gönüllü olarak bir araya gelmiş insan topluluğunu ima eder. Klüp, siyasi parti, kilise, lobi, çıkar grubu gibi oluşumlar birliğe (association) girmektedir. Young'a göre, birlikler (association) bireyin hayatını etkilese de kimliğini tanımlamada dikkate alınmaz. Gruba mensubiyet ise, Heidegger'in "fırlatılmışlık" dediği şeyin özelliğine sahiptir. Kişi kendini bir grubun üyesi olarak bulur ve bu grup kişinin kimliğini belirler. Ancak bu elbette ki kişinin o gruptan ayrılıp, başka bir gruba üye olamayacağı anlamına gelmez. ${ }^{53}$ Young, kiliseyi gönüllü topluluk olan birlik (association) kategorisinde değerlendirirken, komüniteryanlar kiliseyi de aile, ulus, etnik topluluk gibi seçimlik olmayan topluluklar kategorisinde değerlendirmektedirler. Bu ayrışmanın dinin ikili kabul biçiminden kaynaklanması muhtemeldir. Din hem seçime dayalı hem de doğuştan kendimizi kültür gibi içinde bulduğumuz bir olgudur. Ancak her halükarda kimliğin bir bileşeni olduğu yadsınamaz.

Yukarıdaki değerlendirmeler ışığında, vatandaşlık teorilerinin özne anlayışlarının, kimliğe bakış açılarını şekillendirdiğini görmekteyiz. Din de dahil olmak üzere, farklı aidiyetlerin, topluluk üyeliklerinin kimliği oluşturucu, şekillendirici rollerinin olduğu artık liberal teori de dahil olmak üzere tüm teorilerin kabul ettiği bir gerçektir. Bununla birlikte, Rawls, Kymlicka, Habermas, Young dini veya diğer toplulukların bireyin kimliği üzerinde belirleyici etkisi olsa da, bireylerin, vatandaşların bu topluluğu eleştirme, kendi istediği hayat tarzına uymuyorsa onu terk etme ve başka bir topluluğa üye olma hakkının korunmasının önemine vurgu yapmaktadırlar. Diğer türlü, dini kimliğin, topluluğun vatandaşın, bireysel hak ve özgürlüklerini kısıtlayıcı bir etkisi olacağını ileri sürmektedirler. Komüniteryan yaklaşımda ise topluluğun, kimliğin birey üzerinde birtakım kısıtlamalara gidebileceği yaklaşımı söz konusudur. Liberal komüniteryan bir çizgide olan Walzer, birtakım kısıtlamaların olabileceğini savunmakla beraber, ${ }^{54}$ topluluktan vazgeçme hakkının da korunması gerektiğini savunur.

52 Chantal Mouffe, The Return of the Political (London: Verso, 1993), 18-21.

53 Young, "Polity and Group Difference", 260-261.

54 Walzer'a göre, mesela, dini bir topluluk, dinden dönen bir mensubunu aforoz edebilir ancak ölüm cezasına çarptıramaz. Berten vd., Liberaller ve Cemaatçiler, 201-202. 


\section{5. Çok Hukukluluk Meselesi}

Vatandaşlık ve dinin kamusal talepleri hakkında ele alacağımız son sorunsal, çok hukukluluk meselesidir. Çokkültürlü/çok dinli toplumlarda dini grupların kendi yaşam tarzlarını sürdürmek için taleplerinden bir tanesi de çok hukuklu sistem talebidir. Buna göre, aile hukuku/medeni hukuk alanında devletin dini gruba yetki vermesi ve grupların bu konularda yargılama yetkisi elde etmesi söz konusudur. Çokkültürcü vatandaşlık teorilerinde, çok hukukluluğu benimseyenler olduğu gibi, bireysel hakların ihlali riski nedeniyle daha temkinli yaklaşanlar da vardır. Evrenselci kanat için ise, bu talep hem grup içi baskı oluşturma, bireysel hak ve özgürlükleri kısıtlamaya yol açma ihtimali hem de böylelikle ortak alanların ortadan kalkması, toplumun parçalanması tehdidini taşıması açısından oldukça tartışmalıdır.

Kymlicka ve Norman, çok hukukluluk taleplerini kültürel haklar kategorisinde değerlendirmektedirler. Etno-dini grupların, kültürel hakları için, Osmanlı'daki millet sistemindeki ya da İsrail ve Hindistan'daki, dini topluluklar arasında farklılaşan medeni hukuk çokkültürcü hoşgörü biçimi olarak değerlendirilebilir. ${ }^{55}$ Ancak Kymlicka, belirli yasa ya da düzenlemelerden muafiyet taleplerinde olduğu gibi, çok hukukluluk talepleri konusunda da, grup haklarının bireysel hakları ihlal etmemesi gerektiğini vurgulamaktadır. Ona göre, çokkültürlü vatandaşlığın insan hakları ile azınlık haklarının/grup haklarının nasıl bir arada var olacağını ve bu hakların, bireysel özgürlük, demokrasi ve toplumsal adalet tarafından nasıl sınırlandırılacağını açıklaması gerekir. Bireysel, insan haklarının korunması ve iki tip hak arasındaki denge önemlidir. Aksi takdirde, Ayelet Shachar'ın çokkültürlü kırılganlığın/hassasiyetin paradoksu (the paradox of multicultural vulnerability) kavramı ile ifade ettiği bir olgunun ortaya çıkma riski vardır. ${ }^{56}$ Shachar, grup içi çeşitliliği göz önünde bulundurmadan, farklı görüşlerin seslerini duyurmasına imkan sağlamaksızın, bir dini grup içerisinden otorite tayin ederek aile hukuku, evlenme, boşanma gibi konularda özel yargılama yetkisinin kendilerine

55 Will Kymlicka-Wayne Norman, "Citizenship in Culturally Diverse Societies: Issues, Contexts, Concepts", Citizenship in Diverse Societies, ed. Will Kymlicka-Wayne Norman (Oxford: Oxfrod University Press, 2003), 28. Çok hukukluluk konusunu ele alan bir diğer isim ise Veit Bader'dir. Bader, dini çeşitlilik konusu ve dinlerin taleplerine ilişkin ilişkisel/birleştirici demokrasi (associative democracy) anlayışını ileri sürmektedir. Liberal bir kurumsal çoğulculuğu savunarak, hem katı sekülerist yaklaşımlardan hem de demokratik, liberal ilkeleri benimsemeyen bir dini kurumsal çoğulculuk anlayışından ayrılarak, üçüncü bir yol ortaya koymaktadır. Osmanlı'daki millet sistemi gibi uygulamalardan ilham alınabileceğini savunurken, kurumsal çoğulculuğun olumsuz taraflarının giderilmesi için, grup içerisindeki incitilebilir azınlıkların korunmasının sağlanmasına yönelik bir takım öneriler ortaya koymaktadır: Birincisi, ilişkisel/birleştirici demokrasi, gruptan çıkış hakları ile birlikte anlamlı çıkış opsiyonları sunmaktadır. İkincisi, dini organizasyonlar içerisindeki tartışmaları teşvik eder. Bunu yaparken, grup özerkliğini ihlal etmemeye özen gösterir. Üçüncüsü, dinlerin tanınması ve kurumsallaşması meşru minimal devlet gözetmenliği ve kontrolüne dair araçları artırır. Dördüncüsü, grup içerisindeki incitilebilir azınlıkların da hakları, çıkarları, temel ihtiyaçları dahil olmak üzere, herkesin hak, çıkar ve temel ihtiyaçlarını korumak zorunda olan farklılaştırılmış bir moralite fikrini etkili hale getirir. Veit Bader, Secularism or Democracy? Associational Governance of Religious Diversity (Amsterdam: Amsterdam University Press, 2007), 19; 29-30.

56 Ayelet Shachar, "On Citizenship and Multicultural Vulnerability", Citizenship: Critical Concepts in Political Science, ed. Richard Bellamy- Madeleine Kennedy-Macfoy (New York: Routledge, 2014), 2/244-246. 
verilmesinin, zayıf konumda olan, risk grubunda olan üyelerin baskılanmasına ve grup hiyerarşisinin güçlendirilmesine yol açacağını iddia etmektedir. Ona göre, bu teorik bir kaygı değildir. İsrail ${ }^{57}$ ve Hindistan gibi vatandaşların evlenme ve boşanma pratiklerini dini gruplara bırakan ülkelerde, kadınların, demokratik süreçte zor kazanılmış bireysel haklarını ihlal eden uygulamalar söz konusudur. ${ }^{58}$ Devletin aile hukuku konusunda dini gruplara yargı hakkı tanıması ve onların bu konularda iç işlerine karışmayan bir politika benimsemesi Shachar'a göre kadınların baskılanmasına yol açmaktadır. Söz konusu baskı konusunda, gruptan çıkma hakkının garanti altına alınmasının bireyleri koruyacağına dair yaklaşım ise zaten zayıf konumda bulunan grup üyelerinin grubu terk etmek için gerekli ekonomik yeterlik, kendine güven, dil yeterliliği vb. özelliklere sahip olmamaları nedeniyle yeterli olmayacaktır. Öte yandan, bireye, tüm anlam dünyasını teşkil eden bir dini grubun ya baskıcı da olsa, vatandaşlık haklarını ihlal de etse, bütün uygulamalarını kabul etmek ya da tamamen onu terk etmek seçeneği dışında bir seçeneğin sunulmaması da problemlidir. Devletin grup içi baskı veya hak ihlalini, "özel alana" ait bir mesele olarak değerlendirip "iç işlerine müdahale etmeme" (nonintervention) yaklaşımı ise bir başka sorunlu noktadır. ${ }^{59}$

Çokkültürcü politikayı benimseyen Kanada, Ontario'da 1991'den beri seküler mahkemeler, boşanma, çocuğun velayeti ve miras davalarında sivil arabuluculuklarda şeriatın kullanımını tanımıştır. Arabuluculuk Yasası ile bireylere il içerisindeki dini olarak temellendirilmiş mahkemelere başvuru izni verilmiştir. Amaç, aşırı yükü olan hukuk sistemini kısmen rahatlatmaktır. Bu sebeple, Yahudilere, Katoliklere de aynı izni tanımıştır. Ancak hem sekülerler hem de Kanada'daki Müslümanlar (özellikle İran'dan gelen sığınmacılar) arasında bu uygulama birtakım itirazlara yol açmıştır. ${ }^{60}$ Bryan Turner, çokkültürcülüğün kabulünün, bizi çok hukukluluğun da kabulüne götürdüğünü ancak bu konuda problemlerin olduğunun göz ardı edilemeyeceğini ileri sürmektedir. Ona göre, kültürel, dini veya yasal farklılıkların korunabilmesi ancak insanları ortak bir topluluğa bağlayan kapsamlı bir vatandaşlık çerçevesi olduğunda mümkün ve sürdürülebilir olacaktır. Bu ortak payda olmadan toplumlar önemli bir tehlike ile karşı karşıyadırlar. Toplumlar, ayrı okullu, çok az mekânsal yakınlığa sahip ve ayrık kültürel geleneklere ve kendi hukuki geleneklerine sahip topluluklara parçalandıklarında, izole edilmiş yerleşim bölgeleri veya paralel toplumlar ortaya çıkacaktır. Toplum, "etrafı çevrili topluluklar"ın basit bir toplamından ibaret olacaktır. Modern toplumlarda kamusal hayatın altını oyan, aktif vatandaşlığın

57 İsrail'de, on üç dini topluluğun (Müslüman, Hıristiyan, Dürziler de dahil olmak üzere), evlenme ve boşanma konusunda kendi geleneklerine göre yargılama yapan özerk mahkemeler kurmalarına ve yürütmelerine izin verilmiştir. Bu doğrultuda, Yahudi, Halakhic hukuku gereğince erkek, evliliği bitirme kararı almadıkça, kadın istemese bile boşanabilmesinin herhangi bir yolu yoktur. Shachar, bu durumu, çokkültürcü uyum politikasının, grup içi baskıya yol açan bir örneği olarak görmektedir. Shachar, "On Citizenship and Multicultural Vulnerability", 255.

58 Shachar, "On Citizenship and Multicultural Vulnerability", 248-254.

59 Shachar, "On Citizenship and Multicultural Vulnerability", 256-257.

60 Turner, Religion and Modern Society, 157-158. 
düşüşüne yol açan bir dizi süreç söz konusudur. Hukuki çoğulculuk da bu doğrultuda, "vatandaşlığın erozyonu"na yol açan bir olgudur. ${ }^{61}$

Turner'a göre, Habermas ve Rawls'un dinin kamusal alana, kamusal tartışmalara katılması konusundaki görüşleri demokrasi düşüncesine önemli katkılar sağlamıştır. Ancak onlar meselenin, sosyolojik zeminini, koşullarını anlamakta eksik kalmışlardır. Rawls, modern politik sistemde bir konsensüsü başarmanın yoluna odaklanmaktadır. Bu noktada örtüşen görüş birliğini vurgulamaktadır. Ancak bugün, dinler arasındaki ayrımların eskisinden daha fazla arttığı, çokkültürlü toplumların kuşatılmış (enclave) toplumlara dönüşme tehlikesinin olduğu bir durum söz konusudur. Anayasal esaslar veya post-seküler değerler üzerindeki ilkesel konsensüs, toplumsal konsensüsten farklıdır ve yeterli değildir. Örtüşen görüş birliği Turner'a göre, örtüşen toplumsal gruplar gerektirir. Yani karşılıklı evlilikler, ortak okul sistemi, ortak deneyimler gerektirir. Bu doğrultuda, çok hukukluluğa doğru giden bir süreç paralel toplumların oluşmasına yol açmakta, örtüşen toplumsal gruplar olgusunu ortadan kaldırmaktadır. ${ }^{62}$

Turner, sosyolojik boyutu vurgulamak noktasında haklı olsa da, Rawls ve Habermas'ın vatandaşlık yaklaşımlarının da ortak kamusal siyasal kültürü korumaya yönelik olduğunu tekrar belirtmek gerekir. Her ikisi de din konusunda, dinin kamusal alanda görünürlüğü ve kamusal/siyasal tartışmalara katılımı konusunda, yukarıda da değinildiği üzere, evrenselci kanatta yer almakta, bireysel hakları savunmaktadırlar ve ortak bir kamusal/siyasal kültürü korumanın önemini vurgulamaktadırlar. Habermas, ayrıca kolektif haklar sağlanmasını yanlış bulmakta, haklar teorisinin tanınma mücadelelerinde kolektif hedeflere zaten yer verdiğini iddia etmektedir. Ancak haklar teorisi içerisinde bile kolektif hedefleri gözetirken, dengenin sağlanması gerektiği ve hukukun yapısının bozulmamasına dikkat edilmesi konusunda uyarmaktadır. ${ }^{63}$ Dolayısıyla, Habermas ve Rawls'un yaklaşımları çok hukukluluk taleplerine olumlu yaklaşmamaktadır.

Mouffe da, radikal demokratik vatandaşlık fikri ile, vatandaşlığı, bireysel özgürlüğü ve politik katılımı uzlaştıran, bireysel hakları ve çoğulculuğu korurken, etiko-politik bir bağlılığı öngören, sivil ilişkinin kurallarını belirleyen bir politik topluluğa üyelik, farklı üyelikleri olan bireylerin ortak politik kimliği olarak tanımlamaktadır.

\section{Sonuç}

Küreselleşme süreciyle birlikte ortaya çıkan çokkültürlü/çok dinli toplumsal yapı, homojen bir toplumsal yapıyı temel alan modern vatandaşlık anlayışının revizyonunu zorunlu kılmaktadır. Söz konusu revizyon girişiminin, dinlerin kamusal alandaki taleplerini de dikkate alacak şekilde gerçekleştirilmesi gerektiği

61 Turner, Religion and Modern Society, 161-162.

62 Turner, Religion and Modern Society, 173-174.

63 Habermas, "Demokratik Hukuk Devletinde Tanınma Mücadelesi", 125. 
de artık yadsınamaz bir gerçeklik olarak anayasal demokrasilerin gündemindedir. Zira özellikle geleneksel dinlerin kamusal taleplerinin yükselişi, Aydınlanma'dan itibaren dini özel alana ait bir olgu olarak değerlendirmeye çalışan bakış açısının artık geçerli olamayacağını göstermektedir. Bu doğrultuda, bu makale, dört temel vatandaşlık teorisinin seçtiğimiz temsilcilerinin modern vatandaşlığın krizine sundukları çözüm önerilerini karşılaştırmalı olarak ele alarak, din ve dini kimlikle ilişkili olarak, din ve vicdan özgürlüğü, ibadet özgürlüğü, kamusal alana katılım, karar alma süreçlerine etki, eşit ve özgür bir şekilde bir arada var olma, dini grupların genel mevzuatlardan muafiyet talepleri gibi konularda ortaya çıkan meselelerin çözümüne ilişkin vatandaşıı temelli sundukları yaklaşımları incelemiştir. Bu teorilerin, vatandaşlık ve genelde toplumsal çeşitlilik, özelde ise din meselesini, özne/kendi (self) anlayışı, toplumsal adalet, bir arada var olma, meşruiyet, farklı kimliklerin tanınması, vatandaşlık haklarının mahiyeti, kamusal alan, anayasal ilkeler, toplumsal entegrasyon gibi konular etrafında ele aldıkları gözlemlenmiştir. Ele aldığımız vatandaşlık teorileri, çokkültürlü/çok dinli toplumlarda, vatandaşlığın, eşitlik ve özgürlüğü temin etmek için yeniden yorumlanması, dini kimlik taleplerinin de diğer kimlik talepleri gibi karşılanması, dindar vatandaşların din temelli görüşlerinin de seküler vatandaşların görüşleri gibi kamusal siyasal tartışmaya katılabilmesi gerektiğini savunma konusunda örtüşmekle birlikte, yani amaç noktasında örtüşmekle birlikte, bunun yöntemi, özne, vatandaş, toplum, topluluk anlayışları, devletin rolü, vatandaşlığın bileşenlerinden hangisi ya da hangilerinin önceleneceği, toplumsal adalet anlayışı gibi konularda ayrışmaktadırlar. Bahsi geçen ayrışmalara sebep olan yalnızca kuramsal farklılaşmalar değil, kuramların ortaya çıktığı toplumların yapısı, demokrasi tecrübesi, farklı kimlik bileşenlerinin o toplumdaki rolü, toplumlarının katastrofik tecrübeleri gibi unsurlardır. Bu nokta, meselenin sosyolojik boyutunu teşkil etmektedir. Öte yandan, vatandaşlığa ilişkin teorik yaklaşımların vurgularından anlaşıldığı üzere dikkat edilmesi gereken bir takım hususlar söz konusudur. Buna göre, kamusal alana katılımda, dindarların kimlik bütünlüğünün korunması, kamusal-özel şeklinde bir kimlik parçalanmasına maruz kalmamaları, dine dayalı görüşlerinin dini bir dille ifade edilmesi nedeniyle kamusal/siyasal tartışma ve karar alma süreçlerine etki edememesinin önüne geçilmesi dikkat edilmesi gereken hususlar olarak karşımızdadır. Modern vatandaşlığın bir kazanımı olan bireysel hakların, temel insan haklarının korunması oldukça önemlidir. Dindar vatandaşların kamusal ve kimlik temelli talepleri karşılanırken benimsenen yaklaşım ister evrenselci yaklaşım olsun, isterse grup haklarını öngören çokkültürcü, partikülarist yaklaşım olsun, dindar vatandaşların bireysel haklarını, temel insan haklarını ihlal edecek uygulamaların, gruplar arası eşitsizliğe, grup içi ya da gruplar arası baskıya yol açacak uygulamaların önüne geçilmesinin gereği aşikardır. Anayasal demokrasilerde, anayasal ilkelerin, temel adalet ilkelerinin dindarlar tarafından benimsenmesi ne kadar önem arz ediyorsa, bu ilkelerin oluşum süreçlerine katılımları da aynı şekilde önem arz etmektedir. 


\section{Kaynakça}

Bader, Veit. Secularism or Democracy? Associational Governance of Religious Diversity. Amsterdam: Amsterdam University Press, 2007.

Berten, André vd. (Ed.). Liberaller ve Cemaatçiler. çev. Başak Demir vd.. Ankara: Dost Kitabevi, 2006.

Casanova, Jose. "Exploring the Postsecular: Three Meanings of "the Secular" and Their Possible Transcendence". Habermas and Religion. ed. Craig Calhoun vd.. 27-48. Cambridge: Polity Press, 2013.

Casanova, Jose. Public Religions in the Modern World. Chicago: Chicago University Press, 1994.

Habermas, Jürgen. Between Naturalism and Religion: Philosophical Essays. çev. Ciaran Cronin. Cambridge: Polity Press, 2008.

Habermas, Jürgen. “Demokratik Hukuk Devletinde Tanınma Mücadelesi”. çev. Illknur Aka. "Öteki" Olmak, "Öteki"yle Yaşamak: Siyaset Kuramı Yazıları. Jürgen Habermas. 111-148. İstanbul: Yapı Kredi Yayınları, 6. Baskı, 2012.

Habermas, Jürgen. Doğalcılık ve Din Arasında: Felsefi Denemeler. çev. Ali Nalbant. İstanbul: Yapı Kredi Yayınları, 2. Baskı, 2012.

Habermas, Jürgen. Kamusallığın Yapısal Dönüşümü. çev. Tanıl Bora ve Mithat Sancar. İstanbul: Illetişim Yayınları, 12. Baskı, 2014.

Habermas, Jürgen. "The Political": The Rational Meaning of a Questionable Inheritance of Political Theology". The Power of Religion in the Public Sphere. Ed. Eduardo MedietaJonathan Vanantwerpen. 15-33. New York: Columbia University Press, 2011.

Kaya, Ayhan-Tarhanlı, Turgut. "Giriş: Türkiye'de Azınlıklar ve Anayasal Yurttaşlık". Türkiye'de Çoğunluk ve Azınlık Politikaları: AB Sürecinde Yurttaşıı Tartışmaları. Drl. Ayhan KayaTurgut Tarhanlı. 9-31. İstanbul: Tesev Yayınları, 2. Baskı, 2006.

Kymlicka, Will. Multicultural Citizenship: A Liberal Theory of Minority Rights. Oxford: Oxford University Press, 2003.

Kymlicka, Will. "Citizenship". Routledge Encyclopedia of Philosophy: Brahman - Derrida, Jacques. Ed. Edward Craig, 2/362-365. London: Routledge, 1998.

Kymlicka, Will-Norman, Wayne. "Citizenship in Culturally Diverse Societies: Issues, Contexts, Concepts". Citizenship in Diverse Societies. Ed. Will Kymlicka-Wayne Norman. 1-41. Oxford: Oxfrod University Press, 2003.

Lister, Michael- Pia, Emily. Citizenship in Contemporary Europe. Edinburgh: Edinburgh University Press, 2008.

Mouffe, Chantal. "Preface: Democratic Politics Today". Dimensions of Radical Democracy: Pluralism, Citizenship, Community. Ed. Mouffe Chantal. 1-14. London: Verso, 2. Baskı, 1995.

Mouffe, Chantal. "Religion, Democracy, and Citizenship". Political Theologies: Public Religions in a Post-Secular World. ed. Hent de Vries-Lawrence E. Sullivan. 318-326. New York: Fordham University Press, 2006.

Mouffe, Chantal. The Return of The Political. London: Verso, 1993. 
Müller, Jan-Werner. Constitutional Patriotism. Princeton: Princeton University Press, 2007.

Olfield, Adrian. "Vatandaşlık Doğal Olmayan bir Pratik mi?”. çev. Can Cemgil. Vatandaşlığın Dönüşümü Üyelikten Haklara. Haz. Ayşe Kadıoğlu. 91-106. İstanbul: Metis Yayınları, 2. Basım, 2012.

Rawls, John. Halkların Yasası ve "Kamusal Akıl Düşüncesinin Yeniden Ele Alınması". çev. Gül Evrin. İstanbul: İstanbul Bilgi Üniversitesi Yayınları, 2. Baskı, 2006.

Rawls, John. Siyasal Liberalizm. çev. Mehmet Fevzi Bilgin. İstanbul: İstanbul Bilgi Üniversitesi Yayınları, 2007.

Ryan, Alan. "John Rawls". çev. Ahmet Demirhan. Çağdaş Temel Kuramlar. Drl. Quentinne Skinner. 133-157. İstanbul: Illetişim Yayınları, 2013.

Shachar, Ayelet. "On Citizenship and Multicultural Vulnerability". Citizenship: Critical Concepts in Political Science. 4 Cilt. Ed. Richard Bellamy-Madeleine Kennedy-Macfoy. 2/243-266. Oxon-New York: Routledge, 2014.

Soysal, Yasemin Nuhoğlu. Limits of Citizenship: Migrants and Postnational Membership in Europe. Chicago: The University of Chicago Press, 1994.

Soysal, Yasemin Nuhoğlu. "Changing Citizenship in Europe: Remarks on Postnational Membership and the National State". Citizenship, Nationality and Migration in Europe. Ed. David Cesarani-Mary Fulbrook. 17-29. London: Taylor\&Francis e-Library, 2003.

Taylor, Charles. "The Politics of Recognition". Multiculturalism: Examining the Politics of Recognition. Ed. Amy Gutmann. 25-73. Princeton: Princeton University Press, 1994.

Taylor, Charles. "Why We Need A Radical Redefiniton of Secularism". The Power of Religion in the Public Sphere. Ed. Eduardo Mendieta-Jonathan VanAntwerpen. 34-59. New York: Columbia University Press, 2011.

Tilly, Charles. "Citizenship, Identity and Social History". Citizenship, Identity and Social History. Ed. Charles Tilly. 1-17. New York: Cambridge University Press, 1996.

Turner, Bryan S.. Religion and Modern Society: Citizenship, Secularisation and the State. Cambridge: Cambridge Univesity Press, 2011.

Young, Iris M. "Polity and Group Difference: A Critique of the Ideal of Universal Citizenship". Ethics. 99/2 (1989), 250-274. 
